\title{
Combining in situ measurements and altimetry to estimate volume, heat and salt transport variability through the Faroe-Shetland Channel
}

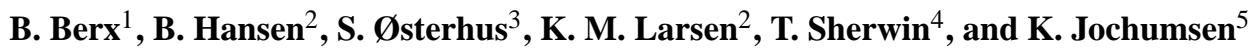 \\ ${ }^{1}$ Marine Scotland Science, Marine Laboratory, P.O. Box 101, Aberdeen, AB11 9DB, UK \\ ${ }^{2}$ Faroe Marine Research Institute, Nóatún 1, P.O. Box 3051, FO 110 Tórshavn, Faroe Islands \\ ${ }^{3}$ Uni Bjerknes Centre, Uni Research and University of Bergen, Norway \\ ${ }^{4}$ Scottish Association for Marine Science, Oban, Argyll, PA37 1QA, UK \\ ${ }^{5}$ Institut für Meereskunde, Universität Hamburg, Bundesstrasse 53, 20146 Hamburg, Germany \\ Correspondence to: B. Berx (b.berx@marlab.ac.uk)
}

Received: 27 November 2012 - Published in Ocean Sci. Discuss.: 17 January 2013

Revised: 13 May 2013 - Accepted: 30 May 2013 - Published: 9 July 2013

\begin{abstract}
From 1994 to 2011, instruments measuring ocean currents (Acoustic Doppler Current Profilers; ADCPs) have been moored on a section crossing the Faroe-Shetland Channel. Together with CTD (Conductivity Temperature Depth) measurements from regular research vessel occupations, they describe the flow field and water mass structure in the channel. Here, we use these data to calculate the average volume transport and properties of the flow of warm water through the channel from the Atlantic towards the Arctic, termed the Atlantic inflow. We find the average volume transport of this flow to be $2.7 \pm 0.5 \mathrm{~Sv}\left(1 \mathrm{~Sv}=10^{6} \mathrm{~m}^{3} \mathrm{~s}^{-1}\right)$ between the shelf edge on the Faroe side and the $150 \mathrm{~m}$ isobath on the Shetland side. The average heat transport (relative to $0{ }^{\circ} \mathrm{C}$ ) was estimated to be $107 \pm 21 \mathrm{TW}\left(1 \mathrm{TW}=10^{12} \mathrm{~W}\right)$ and the average salt import to be $98 \pm 20 \times 10^{6} \mathrm{~kg} \mathrm{~s}^{-1}$. Transport values for individual months, based on the ADCP data, include a large level of variability, but can be used to calibrate sea level height data from satellite altimetry. In this way, a time series of volume transport has been generated back to the beginning of satellite altimetry in December 1992. The Atlantic inflow has a seasonal variation in volume transport that peaks around the turn of the year and has an amplitude of $0.7 \mathrm{~Sv}$. The Atlantic inflow has become warmer and more saline since 1994, but no equivalent trend in volume transport was observed.
\end{abstract}

\section{Introduction}

The flow of warm and saline water of Atlantic origin across the Greenland-Scotland Ridge into the Nordic seas (Hansen and Østerhus, 2000) is the main oceanic mechanism for importing heat and salt from the Atlantic to the Arctic. Through its heat import this flow, the Atlantic inflow, keeps large areas free of ice and much warmer than would otherwise be the case, and thereby creates favourable conditions for fish stocks of great economic importance (see for example Lehodey et al., 2006). Through its salt import it allows the waters in the Arctic Mediterranean (Nordic seas and Arctic Ocean) to maintain a sufficiently high density for atmospheric cooling to produce the dense water masses that return to the Atlantic Ocean as deep overflow to feed the deep branch of the North Atlantic thermohaline circulation (Hansen and Østerhus, 2000).

The Atlantic inflow is carried by three separate branches (Fig. 1), one west of Iceland, one between Iceland and the Faroes, and one through the Faroe-Shetland Channel (FSC). The last of these three branches is the focus of this study. The FSC is a deep channel running between the Faroe Islands and Shetland in a south-westward direction from depths of more than $2000 \mathrm{~m}$ in the Norwegian Sea to a sill of around $1000 \mathrm{~m}$ depth slightly southeast of the southernmost tip of the Faroe Plateau (Fig. 2). From there, it deepens westward and is bounded by the Wyville Thomson Ridge before turning north-westward into the Faroe Bank Channel. 


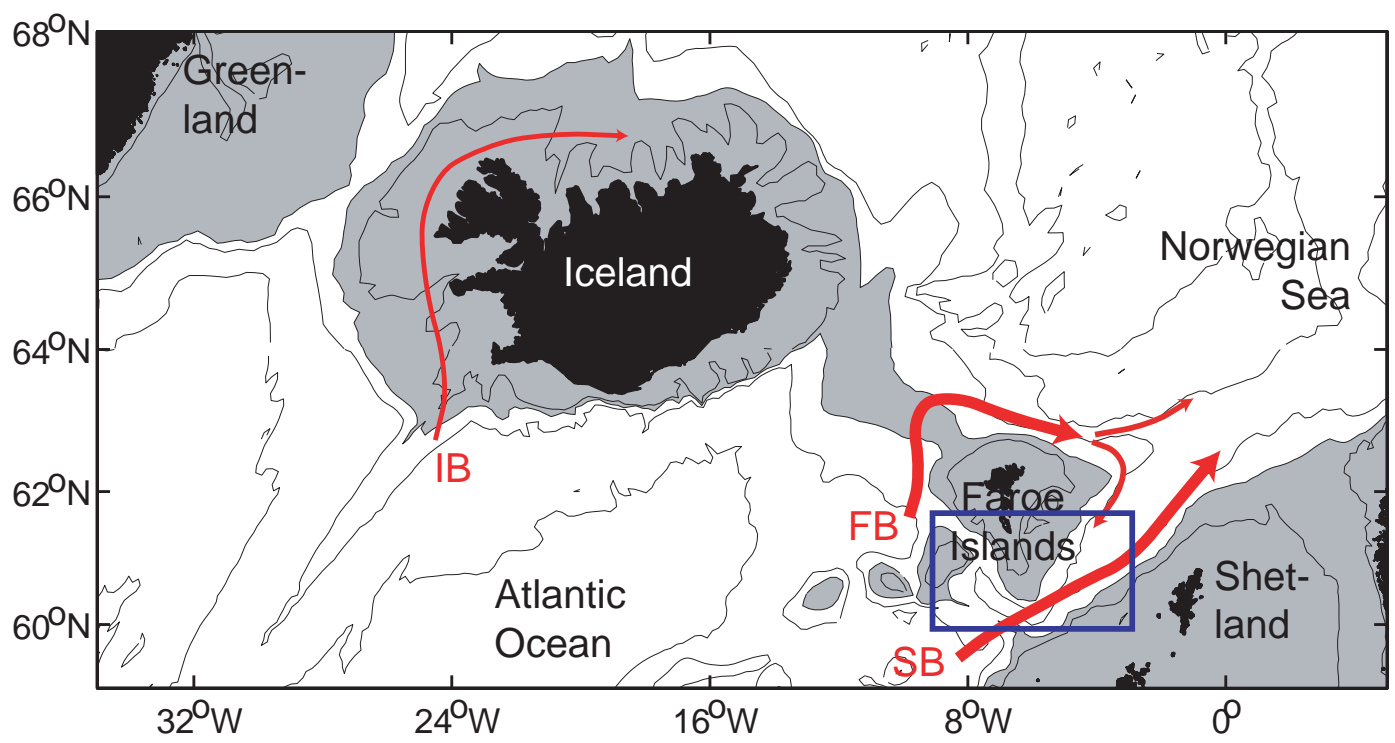

Fig. 1. The Greenland-Scotland Ridge region (grey areas are shallower than $500 \mathrm{~m}$ ) with the three Atlantic inflow branches shown with red arrows: the Iceland branch (IB), the Faroe branch (FB), and the Shetland branch (SB), which is the main focus of this study. The blue rectangle indicates the region shown in more detail in Fig. 2.

Water masses of many different origins are found in the FSC (Hansen and Østerhus, 2000). In the upper layers, two different water masses are present: North Atlantic water (NAW) over the west Shetland slope and Modified North Atlantic water (MNAW) towards the centre of the FSC and Faroese slope. Eastern North Atlantic water arrives from the Rockall Trough and flows along the west Shetland slope in the Continental Slope Current (Souza et al., 2001; Hughes and Turrell, 2004). This water, known as NAW, is warmer and more saline than the Atlantic waters found in the upper layers over the deeper part of the channel. As shown in Fig. 1, some of the Atlantic inflow from the Faroe Branch (FB) turns into the FSC to flow south-westward along the Faroese side of the FSC. Helland-Hansen and Nansen (1909) first proposed this current, and it was later termed the "Southern Faroe Current" by Hátún (2004). This water mass carried by this current, known as MNAW, has a lower salinity and temperature than NAW and may be found further offshore and along the Faroese shelf.

Below this Atlantic water, at least three other water masses are commonly found: Modified East Icelandic Water (MEIW; Read and Pollard, 1992), Norwegian Sea Arctic Intermediate Water (NSAIW; Blindheim, 1990), and Norwegian Sea Deep Water (NSDW; Blindheim, 1990). These three cold and relatively fresh water masses contribute to the deep flow that passes south-westwards through the FSC and continues as overflow over the Wyville Thomson Ridge (Sherwin and Turrell, 2005; Sherwin et al., 2008a) and through the Faroe Bank Channel (Hansen and Østerhus, 2007).

Hydrographic data have been collected from two standard hydrographic sections in the FSC on a regular basis since
1893 by researchers from many nations, although the most consistent effort has been by Marine Scotland Science (MSS) and Faroe Marine Research Institute (FAMRI). These data have provided a fair overview of the properties and distribution of water masses in the channel (Hansen and Østerhus, 2000; Hughes et al., 2006) and their changes through time (Holliday et al., 2008; Larsen et al., 2012). There also have been attempts to estimate the volume transport of Atlantic water through the FSC, based solely on hydrographic data and using geostrophy (Tait, 1957; van Aken, 1988; Schlichtholz and Jankowski, 1993).

Regular monitoring of the Atlantic inflow through the channel by direct current measurements was established on one of these sections, the Fair Isle-Munken section, in 1994 by the Nordic WOCE project, which also included measurements in the other two Atlantic inflow branches (west of Iceland and between Iceland and Faroe Islands). These measurements have been continued with support from the European Union funded VEINS, MAIA, MOEN and THOR projects.

The results from a preliminary attempt to estimate the volume transport of Atlantic water through the FSC that combined hydrographic and velocity measurements (Hughes et al., 2006) were included in the Østerhus et al. (2005) overview of the total Atlantic inflow carried by all the branches. A number of problems make it difficult to produce unambiguous transport estimates, however, and a complete analysis of the full data set has not previously been published in the peer reviewed literature.

In this study, we rectify this omission by presenting a consistent analysis of the entire data set up to recent times. Our main aim is to determine average values for the volume, heat 


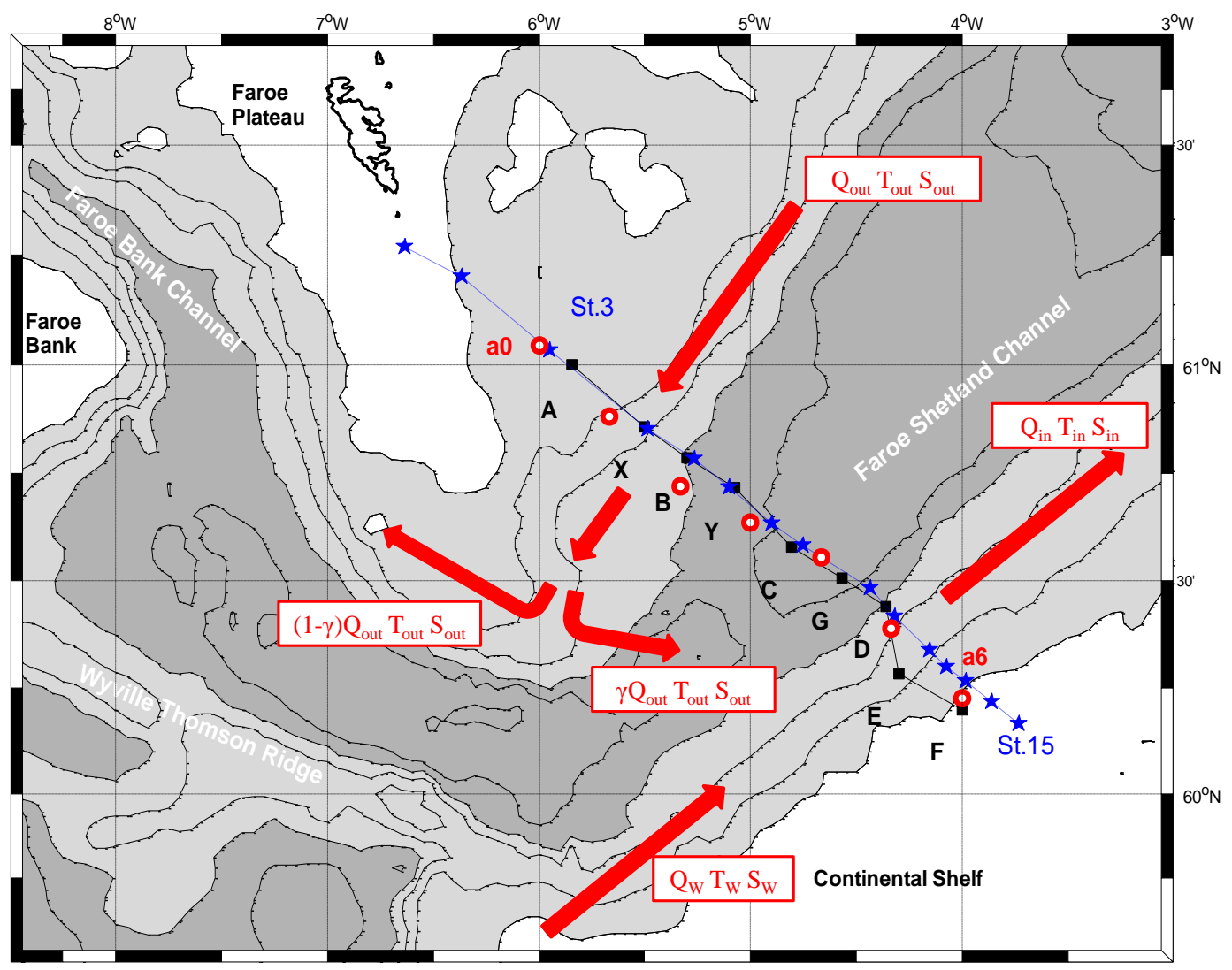

Fig. 2. Map of the Faroe-Shetland Channel with the locations of the observations. Stars show standard CTD stations (Fair Isle-Munken section) and squares show ADCP mooring locations. Red circles indicate altimetry grid points. The contour interval of the bottom topography is $200 \mathrm{~m}$; white areas are shallower than $200 \mathrm{~m}$; dark grey areas are deeper than $800 \mathrm{~m}$. For explanation about the arrows, please refer to Part 6.2 in the text.

and salt transport of the Atlantic inflow through the FSC which is of particular importance for the total mass budget for the Arctic Mediterranean. We further aim to establish the seasonal variation and, perhaps most importantly, long-term trends that may have climatic implications (e.g. IPCC, see Bindoff et al., 2007).

During the observational period, it has become clear that mesoscale activity in the channel introduces a high level of variability that reduces the significance of transport estimates (Sherwin et al., 1999, 2006). To address this problem, we include measurements of sea level height (SLH) in the FSC from satellite altimetry. Within MAIA (Monitoring the Atlantic Inflow toward the Arctic; McClimans et al., 2003), an attempt was made to predict volume transport of Atlantic water from the sea level difference between Tórshavn and Lerwick. Their initial algorithm had to be reviewed during the validation period due to taking an overly simplistic view of processes in the FSC, and it has since remained unvalidated. By choosing altimetry grid points near the shelf edges, we remove the uncertainty due to more coastal physical processes which may have hampered the MAIA effort. Lack of geoid accuracy, however, limits the altimetry data to relative val- ues, but by combining them with our in situ observations, we can calibrate them to obtain absolute transport values for the entire altimetry period.

\section{Data and methods}

\subsection{Temperature and salinity data}

We present data collected along the Fair Isle-Munken (FIM) standard section, hereafter referred to as the section, between 1994 and 2011 when there were a total of 105 occupations. This section has 15 standard stations (Figs. 2 and 3a), from which vertical profiles of temperature and salinity were collected using a CTD (conductivity temperature depth) recorder. Inclement weather, instrument failure, and differing priorities at the two institutes reduces data coverage.

The section has usually been occupied six times a year with a reasonable monthly spread: mainly in February, May, September, October, November, December; although there have been no occupations in January and very few in MarchApril and July-August. During the last two years of the study logistical problems have reduced the coverage and the most 
representative data set therefore covers only 1995-2009 (reducing the total number of occupations from 105 to 99 ).

\subsection{ADCP data}

Current velocity data were collected using RD Instruments (RDI) Broadband and Long Ranger acoustic Doppler current profilers (ADCP) moored along the section (Fig. 2 and 3a). The deployments can be distinguished into two periods. During the first one, from November 1994 to May 2009, 4 ADCP moorings ( $\mathrm{B}, \mathrm{C}, \mathrm{D}$, and $\mathrm{E}$ ) were deployed across the FSC with an additional site (A) occupied on the Faroe Shelf during the first $5 \mathrm{yr}$. During the second period, between May 2009 and May 2011, 7 ADCP moorings were deployed in the FSC. The data return of the ADCP mooring deployments and details of the sites are shown in Fig. 3b and Table 1, respectively. The FSC is heavily fished and most instruments had to be deployed at fairly large depths with the shallow sites protected either by special frames (moorings $\mathrm{A}$ and $\mathrm{X}$ ) or by being placed in a fisheries restricted zone (mooring $\mathrm{E}$ ).

There is a high level of non-stationarity in the tidal currents of the FSC due to the presence of a large internal tidal signal (Sherwin, 1991; Hall et al., 2011). As part of the preliminary data quality control (see Hughes et al., 2006) the tidal signal was removed using a $72 \mathrm{hr}$ low pass filter (Godin, 1968). Transport has been calculated using the along-channel component velocity, which is defined to be perpendicular to the section (i.e. towards $38^{\circ}$, see Fig. 2). This component was extrapolated to the surface and sea bed from the vertical shear for each profile, with limiting threshold values used to prevent overestimation in the near-surface and near-bed regions (see Hughes et al., 2006). For consistency, all the ADCP profiles were then interpolated onto standard depth intervals (bins) of $25 \mathrm{~m}$.

At site $\mathrm{C}$, current meter data from below the ADCP mooring were added to extend the vertical profile towards the sea bed. These were collected using a conventional current meter (Aanderaa RCM7) deployed on the mooring line at a depth of $\sim 760 \mathrm{~m}(\sim 310 \mathrm{~m}$ above the bed and $\sim 105 \mathrm{~m}$ below the ADCP). At sites D and E, ADCP records from the North West Approaches Group (NWAG) were merged during the period 1994-2005 (Hughes et al., 2006) to fill data gaps (see also Appendix 1 in Sherwin et al., 2008b).

\subsection{Altimetry data}

We expect geostrophic balance to apply on monthly timescales, and the sea level slope across the channel should therefore be linked to the surface velocity. Without a sufficiently accurate geoid, absolute values are unreliable, but variations in sea level change should reflect variations in surface velocity. Sea surface height variations were obtained as monthly averaged sea level data between December 1992 and September 2011 on a $1 / 3^{\circ} \times 1 / 3^{\circ}$ Mercator grid (this grid approximates to $\sim 18 \mathrm{~km} \times 18 \mathrm{~km}$ resolution in the FSC).

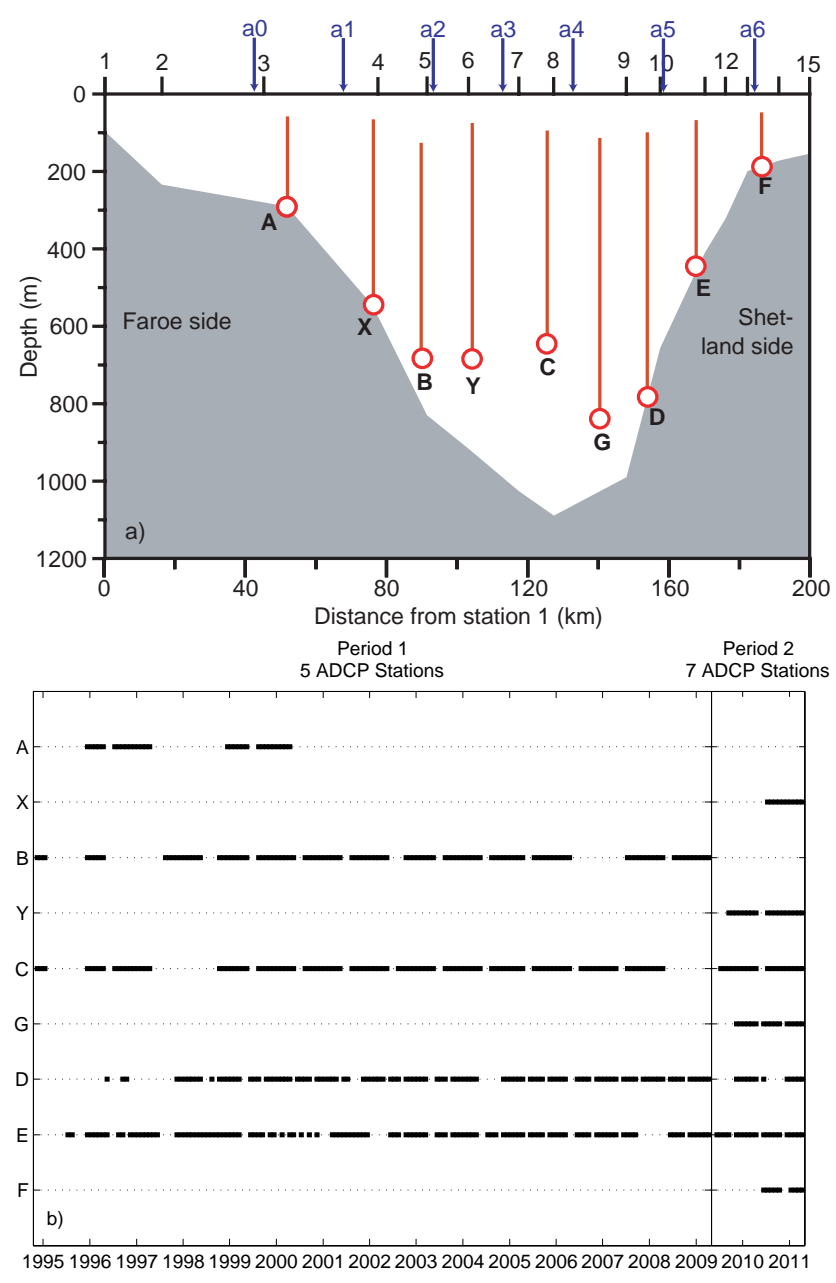

Fig. 3. (a) The observational cross section showing CTD stations 1 to 15 (black numbers) on the top axis and moored ADCPs as red circles with their typical range indicated by vertical red lines. Blue arrows show altimetry grid points a0 to a6. (b) Overview of months with valid deployments at all 9 ADCP sites across the FSC.

These altimeter products were produced by Ssalto/Duacs and distributed by Aviso, with support from Cnes (http://www. aviso.oceanobs.com/duacs/).

Six of these grid points are close to the section and, with an additional point in the middle of the channel constructed by averaging two altimetry grid points, we obtain 7 nearly equidistant data points, labelled a0 to a6 (Figs. 2 and 3a), between station 3 and station 13 of the section.

\section{Observational results}

\subsection{Temperature and salinity}

A number of authors have reported the hydrographic properties observed in the FSC (such as Turrell et al., 1999b) and we will not discuss these in detail here. Our observed 
Table 1. Metadata of ADCP moorings sites: site name, position, bottom depth, depth of the deepest bin (bin 1) measured by the ADCP, average depth of the $5^{\circ} \mathrm{C}$ isotherm, distance from CTD station 1, and representative width used in Eq. (2). Two columns of width are reported due to the mooring array comprising either $4(\mathrm{P} 1)$ or $7(\mathrm{P} 2)$ sites; see text for details (n.a. indicates the entire water column is warmer than $5^{\circ} \mathrm{C} ; \mathrm{P} 1$ = Period 1 = Nov. 1994-May 2009; P2 = Period 2= May 2009-May 2011).

\begin{tabular}{|c|c|c|c|c|c|c|c|c|}
\hline \multirow[t]{2}{*}{ Site } & \multicolumn{2}{|c|}{ Position } & \multirow[t]{2}{*}{$\begin{array}{r}\text { Bottom } \\
(\mathrm{m})\end{array}$} & \multicolumn{2}{|c|}{ Depth of } & \multirow{2}{*}{$\begin{array}{r}\text { Distance } \\
\text { from } \\
\text { stat. } 1 \\
(\mathrm{~km})\end{array}$} & \multicolumn{2}{|c|}{$\begin{array}{l}\text { Width } \\
(\mathrm{km})\end{array}$} \\
\hline & & & & $\begin{array}{r}\text { Bin } 1 \\
(\mathrm{~m})\end{array}$ & $\begin{array}{r}5^{\circ} \mathrm{C} \\
(\mathrm{m})\end{array}$ & & $\mathrm{P} 1$ & $\mathrm{P} 2$ \\
\hline A & $61.000^{\circ} \mathrm{N}$ & $5.844^{\circ} \mathrm{W}$ & 295 & 278 & n.a. & 51.9 & 25.8 & 19.0 \\
\hline $\mathrm{X}$ & $60.859^{\circ} \mathrm{N}$ & $5.502^{\circ} \mathrm{W}$ & 539 & 520 & 389 & 76.2 & - & 26.2 \\
\hline B & $60.785^{\circ} \mathrm{N}$ & $5.302^{\circ} \mathrm{W}$ & 786 & 642 & 387 & 89.8 & 36.8 & - \\
\hline $\mathrm{Y}$ & $60.715^{\circ} \mathrm{N}$ & $5.077^{\circ} \mathrm{W}$ & 909 & 668 & 398 & 104.3 & - & 24.7 \\
\hline $\mathrm{C}$ & $60.579^{\circ} \mathrm{N}$ & $4.801^{\circ} \mathrm{W}$ & 1069 & 617 & 422 & 125.5 & 32.1 & 18.1 \\
\hline $\mathrm{G}$ & $60.508^{\circ} \mathrm{N}$ & $4.567^{\circ} \mathrm{W}$ & 1044 & 810 & 458 & 140.5 & - & 14.2 \\
\hline $\mathrm{D}$ & $60.441^{\circ} \mathrm{N}$ & $4.362^{\circ} \mathrm{W}$ & 801 & 759 & 503 & 154.0 & 21.2 & 13.6 \\
\hline $\mathrm{E}$ & $60.283^{\circ} \mathrm{N}$ & $4.301^{\circ} \mathrm{W}$ & 447 & 420 & n.a. & 167.8 & 16.2 & 16.2 \\
\hline $\mathrm{F}$ & $60.200^{\circ} \mathrm{N}$ & $4.001^{\circ} \mathrm{W}$ & 172 & 160 & n.a. & 186.4 & 23.1 & 23.1 \\
\hline
\end{tabular}

temperature and salinity distribution on the section (Fig. 4) are consistent with these previous findings.

Time series of the mean temperature and salinity between 50 and $100 \mathrm{~m}$ were generated for each station. The seasonal variation of each series was then determined using a least squares method by fitting a sinusoidal harmonic with a periodicity of 12 months (e.g. Emery and Thomson, 1997). The residual series, after seasonal variation had been removed, were then regressed linearly on time (see Table 2 ). Across the section, there has been an increase of $\sim 0.5^{\circ} \mathrm{C}$ in temperature and $\sim 0.075$ in salinity per decade between 50 and $100 \mathrm{~m}$. Our data thus confirm that there has been a general warming and salinification of the Atlantic inflow since 1992 (Holliday et al., 2008; Larsen et al., 2012; Hughes et al., 2011).

Most of the Atlantic water on the section is warmer than $8^{\circ} \mathrm{C}$, whereas the colder water masses from the north are typically colder than $2^{\circ} \mathrm{C}$. We therefore define the $5^{\circ} \mathrm{C}$ isotherm as the boundary between Atlantic water and other water masses. On average, this boundary deepens from less than $400 \mathrm{~m}$ over the Faroe side to more than $500 \mathrm{~m}$ on the Shetland side of the channel (Fig. 4a), but it may vary considerably (Table 2). The depth of the $5^{\circ} \mathrm{C}$ isotherm does not have a statistically significant long-term trend.

\subsection{Atlantic water velocities from ADCP data}

Our main interest is the Atlantic water flow through the FSC, and we will therefore focus on the upper layers that are dominated by Atlantic water across the section. The depth of the Atlantic layer, as determined from CTD measurements, varies considerably in space and time, but is only known as snapshots from individual cruises. The average \pm the standard deviation of the $5{ }^{\circ} \mathrm{C}$ isotherm is deeper than at least $320 \mathrm{~m}$ for all the stations (Table 2), and therefore averaging velocities between 0 and $325 \mathrm{~m}$ depth (the uppermost 13 bins
Table 2. Statistics and long-term trends of temperature, salinity, and the $5^{\circ} \mathrm{C}$ isotherm at the various CTD stations. The first columns show the trend and its $95 \%$ confidence interval of the temperature and salinity in the 50-100 m depth interval. The last columns show the average (Avg), the standard deviation (St.dev.), and the trend of the depth of the $5^{\circ} \mathrm{C}$ isotherm for each standard station of sufficient depth. The trends are determined as the regression coefficient \pm its $95 \%$ confidence interval, based on a linear regression analysis of the seasonal residuals on time.

\begin{tabular}{lccccc}
\hline CTD & Temperature & Salinity & \multicolumn{3}{c}{$5{ }^{\circ}$ C-isotherm Depth } \\
\cline { 3 - 6 } Site & $\begin{array}{c}\text { Trend } \\
\left({ }^{\circ} \mathrm{C} \mathrm{yr}^{-1}\right)\end{array}$ & $\begin{array}{c}\text { Trend } \\
\left(\mathrm{yr}^{-1}\right)\end{array}$ & $\begin{array}{c}\text { Avg } \\
(\mathrm{m})\end{array}$ & $\begin{array}{c}\text { St.dev. } \\
(\mathrm{m})\end{array}$ & $\begin{array}{c}\text { Trend } \\
\left(\mathrm{m} \mathrm{yr}^{-1}\right)\end{array}$ \\
\hline 2 & $0.05 \pm 0.02$ & $0.007 \pm 0.001$ & & & \\
3 & $0.08 \pm 0.02$ & $0.008 \pm 0.001$ & & & \\
4 & $0.06 \pm 0.02$ & $0.008 \pm 0.002$ & 388 & 66 & $3 \pm 2$ \\
5 & $0.05 \pm 0.03$ & $0.008 \pm 0.002$ & 387 & 67 & $3 \pm 3$ \\
6 & $0.06 \pm 0.03$ & $0.009 \pm 0.003$ & 399 & 75 & $2 \pm 3$ \\
7 & $0.06 \pm 0.03$ & $0.008 \pm 0.003$ & 414 & 81 & $2 \pm 4$ \\
8 & $0.04 \pm 0.02$ & $0.006 \pm 0.003$ & 425 & 86 & $1 \pm 4$ \\
9 & $0.05 \pm 0.02$ & $0.006 \pm 0.003$ & 479 & 91 & $1 \pm 4$ \\
10 & $0.05 \pm 0.02$ & $0.006 \pm 0.002$ & 525 & 66 & $1 \pm 3$ \\
11 & $0.05 \pm 0.02$ & $0.006 \pm 0.002$ & & & \\
12 & $0.04 \pm 0.02$ & $0.006 \pm 0.002$ & & & \\
13 & $0.04 \pm 0.02$ & $0.005 \pm 0.001$ & & & \\
14 & $0.03 \pm 0.02$ & $0.006 \pm 0.003$ & & & \\
15 & $0.03 \pm 0.02$ & $0.007 \pm 0.002$ & & & \\
\hline
\end{tabular}

of the extrapolated ADCP data) should give a fair representation of the flow of Atlantic water.

Time series of monthly averaged flow were calculated at each ADCP location by averaging the along-channel (i.e. towards $38^{\circ}$ ) velocity of the layer from the surface to $325 \mathrm{~m}$ depth (or to the deepest bin at the shallow A and F sites). Only months with at least 28 days of observations were 

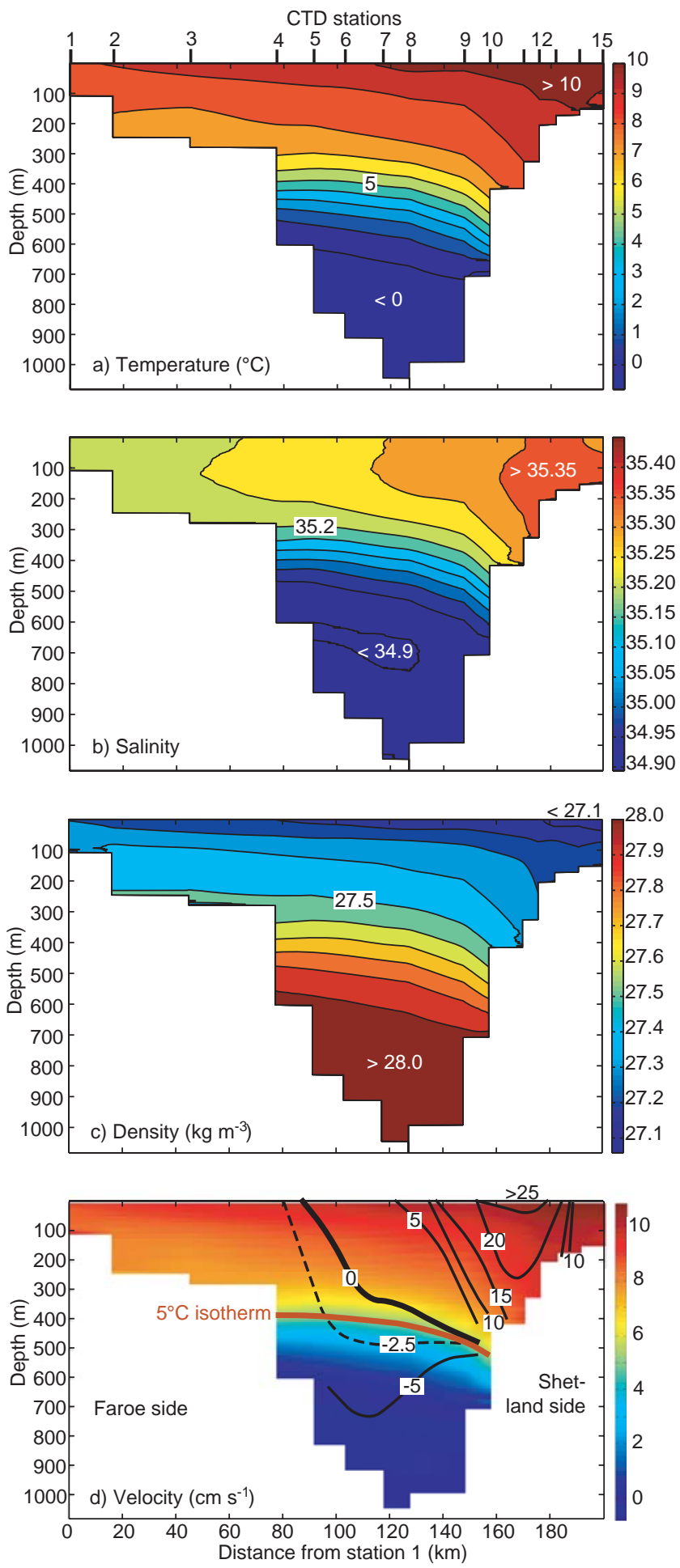

Fig. 4. Averages for the period 1995-2009 of temperature (a), salinity (b), density $\left(\sigma_{t}\right)(\mathbf{c})$, and along-channel velocity superposed on the average temperature distribution (d). The velocities are based on geostrophy from CTD data corrected with altimetry-adjusted velocity data using the core interpolation. The average depth of the $5^{\circ} \mathrm{C}$ isotherm along the section is indicated by the brown line on (d). included. These series will be referred to as the $A W$ velocity for each site.

The characteristics and variations of this parameter are listed in Table 3 for each of the long-term deployment sites (B, C, D, and E). The table also shows results of a least squares seasonal analysis (Emery and Thomson, 1997). The records indicate maximum flow in winter with December being the month of maximum speed for site $\mathrm{D}$, which had the highest $R^{2}$ value and was the only result significant at the $95 \%$ significance level. Site $C$, and to some approximation site $\mathrm{E}$, show the same seasonality although without such statistical confidence. These results are in agreement with the previous estimates of seasonality by Sherwin et al. (2008b), and with those by Dickson et al. (1986) in the Rockall Channel. Other processes, such as eddies and internal waves, contribute to current strength variability in the FSC, and may cause the variability being explained by a seasonal cycle to be relatively small..

Long-term trends of AW velocity at the four main sites (B, C, D and E) were determined by linear regression of the AW velocity on time after removal of the seasonal variation (Table 3). At site E, the results imply a trend statistically different from zero (indicating a decrease in the Atlantic inflow strength), but this analysis assumes no serial correlation (i.e. observations in consecutive months are independent). In time-series analysis, this assumption is often violated, and a Durbin-Watson test (Durbin and Watson, 1951) confirms statistically significant serial correlation at site E at the $95 \%$ significance level. This correlation weakens confidence to the extent that it is not possible to say whether the trends are significantly different from zero.

\subsection{Comparing ADCP and altimetry data}

From geostrophy, the difference in sea level between two altimeter points should be proportional to the surface velocity in the region between them. The vertical variation of the velocity in the upper layers (as seen in ADCP profile data, average profiles are shown in Fig. 5) is relatively small. We therefore correlate AW-velocities measured by the ADCPs with sea level differences. Except for ADCP site A, the correlation coefficients all exceed 0.6 (Table 4). Based on these good correlations, we have regressed the measured ADCP AWvelocities on the sea level differences. We can then compute AW-velocities at the ADCP sites based on altimetry observations for the whole altimetry period using these regression coefficients. We focus on the 1995-2009 period with regular CTD data and define altimetry-adjusted $A W$-velocities by averaging over this period. For the long-term ADCP moorings $(\mathrm{B}, \mathrm{C}, \mathrm{D}$, and $\mathrm{E})$, the average properties and seasonality of the adjusted values agree with the original measured values within the standard error, but for some of the shorter series, there are considerable differences (Table 4). 
Table 3. Varibility of AW velocity (see text for definition) for the four long-term ADCP locations. The table lists the number of months, series average, and standard error. Then the results of fitting to a sinusoidal seasonal variation: amplitude, month of maximum velocity, and the $R^{2}$ value for the fit. The last column shows the long-term trend with $95 \%$ confidence limit, based on a linear regression analysis of the seasonal residuals on time.

\begin{tabular}{|c|c|c|c|c|c|c|c|}
\hline \multirow[t]{2}{*}{ Site } & \multicolumn{3}{|c|}{ Series statistics } & \multicolumn{3}{|c|}{ Seasonal analysis } & \multirow{2}{*}{$\begin{array}{c}\text { Long-term } \\
\text { Trend } \\
\mathrm{cm} \mathrm{s}^{-1} \mathrm{yr}^{-1}\end{array}$} \\
\hline & Months & $\begin{array}{r}\text { Avg } \\
\mathrm{cm} \mathrm{s}^{-1}\end{array}$ & $\begin{array}{l}\text { St. err. } \\
\mathrm{cm} \mathrm{s}^{-1}\end{array}$ & $\begin{array}{l}\text { Amplitude } \\
\mathrm{cm} \mathrm{s}^{-1}\end{array}$ & Maximum & $R^{2}$ & \\
\hline B & 113 & -2.8 & 1.0 & 2.2 & Sep & 0.024 & $0.4 \pm 0.5$ \\
\hline $\mathrm{C}$ & 135 & 1.8 & 0.8 & 2.5 & Dec & 0.030 & $-0.1 \pm 0.3$ \\
\hline $\mathrm{D}$ & 121 & 17.5 & 1.5 & 5.6 & Dec & 0.061 & $0.4 \pm 0.7$ \\
\hline $\mathrm{E}$ & 138 & 21.9 & 1.0 & 0.8 & Jan & 0.003 & $-0.7 \pm 0.4$ \\
\hline
\end{tabular}
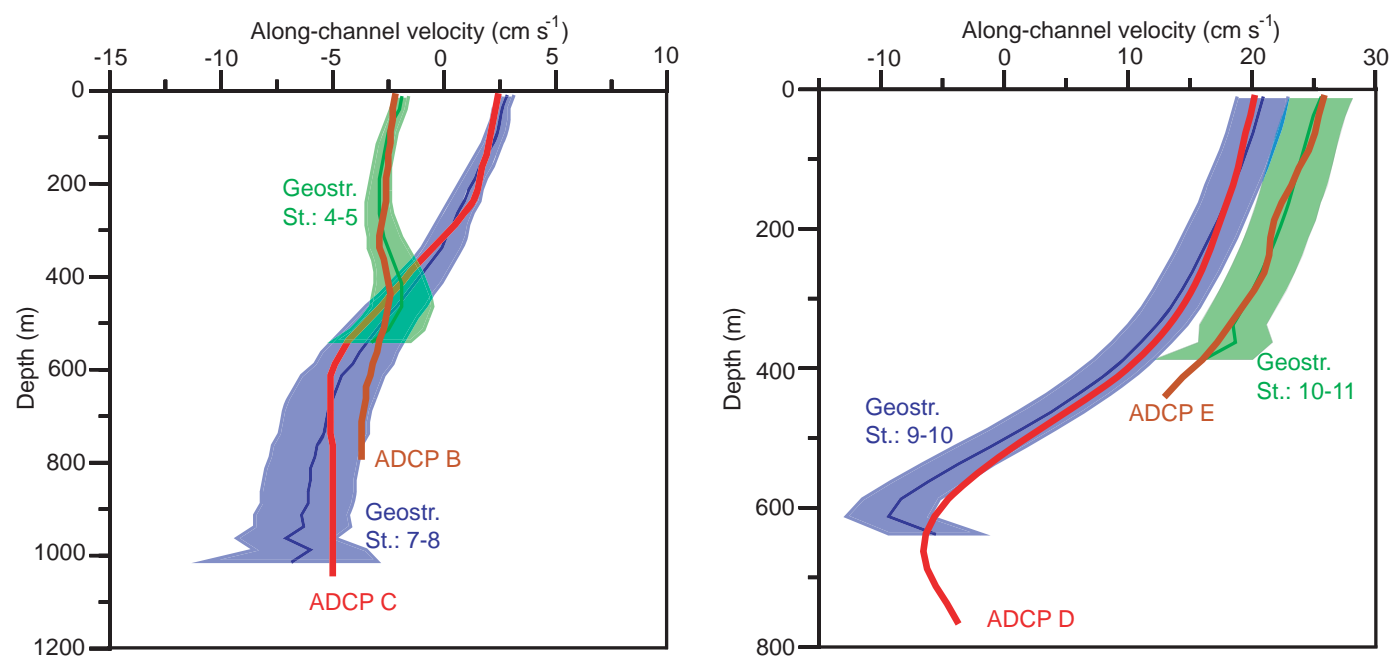

Fig. 5. Comparison of vertical velocity profiles from ADCP and geostrophy (based on CTD profiles between 1995-2009). The geostrophic profiles are illustrated by the average profile (blue or green line) surrounded by an area (blue or green) representing the average \pm the standard error. The geostrophic profiles have been offset so that the average velocity between 0 and $325 \mathrm{~m}$ for each station pair fits the AW velocity of the ADCP.

\subsection{Combining altimetry-adjusted AW-velocities and geostrophic profiles}

From the temperature and salinity data, geostrophic velocity profiles for each cruise were calculated from each pair of neighbouring CTD stations and averaged over the 19952009 period. The data from the long-term ADCP sites (B, C, $\mathrm{D}$, and $\mathrm{E})$ cover the same period, but at a different sampling frequency. A comparison of the moored ADCP data with the geostrophic velocity profiles confirms the assumption of geostrophy in the long-term mean (Fig. 5). The ADCP data can thus be used to assign absolute values to the geostrophic profiles.

In order to also cover a sufficiently long averaging period for the short-term ADCPs ( $\mathrm{X}, \mathrm{Y}, \mathrm{G}$ and $\mathrm{F}$ ), we use the altimetry-adjusted average values (Table 4). The averaged geostrophic velocity profiles have therefore been offset so that the average in the uppermost $325 \mathrm{~m}$ equals the altimetryadjusted AW-velocities for that station pair. This involves in- terpolation between the mooring sites, and two alternative interpolation schemes are illustrated in Fig. 6.

In the "linear" interpolation scheme, the velocity was assumed to vary linearly between the ADCP sites (black line in Fig. 6). The altimetry-adjusted AW-velocities are then interpolated similarly between each set of station pairs, and the geostrophic profiles are adjusted to correspond to these values (red line in Fig. 6).

In the core of a strong flow, the linear interpolation scheme may underestimate the transport. This could be of particular importance on the Shetland side where the uniformity of vertical profiles of temperature and salinity between CTD station 10 and 15 suggest a fairly uniform current. This is not the case at site $\mathrm{X}$ on the Faroe side where the vertical variability at stations 4 and 5 is much higher compared to the Shetland side of the FSC, suggesting the core solution would be less applicable here. As a next step, we applied the alternative "core" interpolation scheme (combined red/blue line in Fig. 6), where it is assumed that the AW velocity in the region 
Table 4. Comparison between monthly averaged AW velocity as measured by the ADCPs (see text for details) and sea level change between corresponding altimetry grid points. The fourth column lists the correlation coefficient between them. The last columns list the average \pm standard error of the AW velocity $\left(\mathrm{cm} \mathrm{s}^{-1}\right)$ based on the ADCP measurements and on the altimetry adjustment, respectively. For the ADCP measurements, the average and standard error are calculated for the months with full data coverage. For the altimetry, the whole period 1995-2009 is used and the altimetry data converted to velocities through linear regression.

\begin{tabular}{llrrrr}
\hline $\begin{array}{l}\text { ADCP } \\
\text { Site }\end{array}$ & $\begin{array}{l}\text { Altim. } \\
\text { Grid }\end{array}$ & Months & $\begin{array}{r}\text { Corr. } \\
\text { coeff. }\end{array}$ & $\begin{array}{r}\text { Average } \pm \text { standard error } \\
\text { ADCP }\end{array}$ & $\begin{array}{r}\text { Altimetry- } \\
\text { adjusted }\end{array}$ \\
& Points & & & & $-2.4 \pm 0.1$ \\
\hline A & a0-a1 & 30 & 0.58 & $-2.2 \pm 0.4$ & $-6.1 \pm 0.6$ \\
X & a1-a2 & 10 & 0.71 & $-8.4 \pm 2.2$ & $-2.3 \pm 0.6$ \\
B & a1-a2 & 112 & 0.80 & $-2.7 \pm 1.0$ & -2.3 \\
Y & a2-a3 & 17 & 0.92 & $-5.4 \pm 2.9$ & $1.4 \pm 0.8$ \\
C & a3-a4 & 135 & 0.67 & $1.8 \pm 0.8$ & $1.8 \pm 0.4$ \\
G & a4-a5 & 16 & 0.89 & $9.0 \pm 2.2$ & $3.9 \pm 0.7$ \\
D & a4-a5 & 120 & 0.87 & $17.5 \pm 1.5$ & $16.1 \pm 1.1$ \\
E & a5-a6 & 134 & 0.74 & $21.4 \pm 0.9$ & $22.3 \pm 0.6$ \\
F & a5-a6 & 11 & 0.74 & $8.5 \pm 0.8$ & $7.8 \pm 0.2$ \\
\hline
\end{tabular}

between stations 10 and 13 equals the altimetry-adjusted AW velocity at site $\mathrm{E}$ (Table 4). The along-channel velocity field, calculated in this way, is illustrated in Fig. 4d. The different interpolation methods suggest an uncertainty of $0.2 \mathrm{~Sv}$ on the volume transport estimate, but sensitivity tests result in a total uncertainty on the order of $0.5 \mathrm{~Sv}$.

\section{Long-term average volume transport of Atlantic water through the FSC}

Once the core interpolation scheme has been chosen, the average volume transport through a specified part of the section may be calculated by integration of the average velocity distribution. Here, we integrate the mean geostrophic profiles combined with the altimetry-adjusted AW-velocities, shown in Fig. 4. Larsen et al. (2008) proposed that a large part of the water over the shallow part of the Faroese shelf circulates around the islands, and this should therefore be excluded from the integration: we start from station 3, close to the Faroese shelf edge, and end at station 15, close to the $150 \mathrm{~m}$ isobath, where observations at site $\mathrm{F}$ indicate the Atlantic inflow is still strong here (Fig. 4 and 6).

If we integrate over this section and down to the bottom at each station, we may obtain an estimate of the inflow and outflow transports across the entire section. We find that the net volume transport is $+0.4 \mathrm{~Sv}$ (directed towards the Norwegian Sea) using core interpolation (Table 5a). This number can be split into two components: an inflow into the Norwegian Sea and an outflow directed to the Atlantic. The former may be calculated by integrating the positive velocities only, the

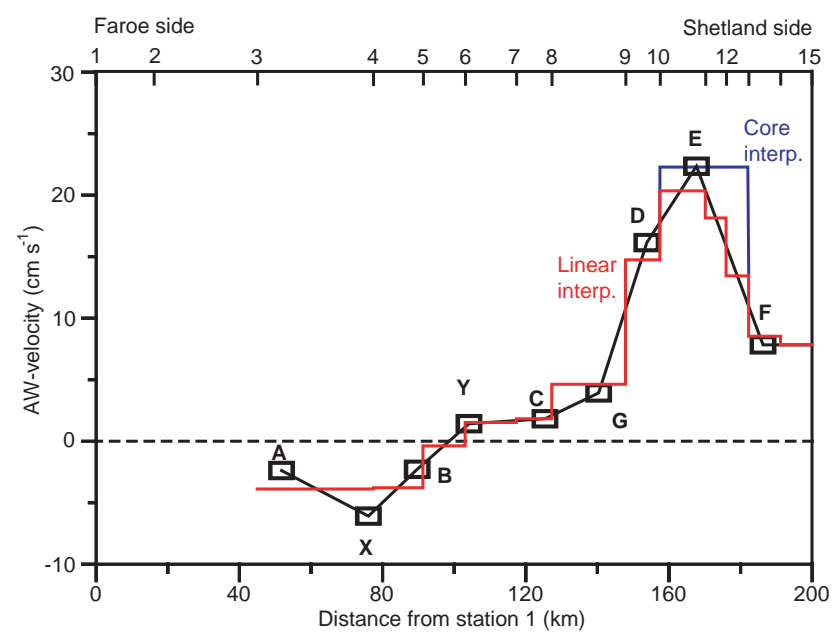

Fig. 6. AW velocity plotted against distance from the first CTD station on the Faroe side (see Fig. 2 for locations). Open rectangles indicate average altimetry-adjusted velocities (last column in Table 4) and the black line shows a linear variation between them. CTD station locations are shown at the top and the red and blue lines indicate AW velocity calculated from the adjusted geostrophic profiles using two alternative interpolation schemes, as discussed in the text.

latter from the negative ones. The inflow component equals $3.5 \mathrm{~Sv}$ and the outflow $-3.1 \mathrm{~Sv}$ : the latter combines a return flow of Atlantic water on the edge of the Faroe Plateau and the dense overflow.

Using the $5{ }^{\circ} \mathrm{C}$ isotherm to delimit the Atlantic water, we can integrate the positive and negative velocities to find the north-eastward and south-westward transports respectively. On the section, we find a transport of $3.5 \mathrm{~Sv}$ of Atlantic water directed towards the Norwegian Sea, and $-0.8 \mathrm{~Sv}$ towards the Atlantic. The estimate of the net Atlantic inflow through the Faroe Shetland Channel is therefore $2.7 \mathrm{~Sv}$. It may be seen in Fig. 7 that the average net inflow would not be affected substantially by choosing a warmer isotherm - up to $8^{\circ} \mathrm{C}$ - to delimit the Atlantic water, since the decreased total inflow would be compensated by decreased total outflow. Using a lower temperature reference than $5^{\circ} \mathrm{C}$ would give a lower net inflow due to increased outflow in the deep parts of the channel. This justifies the choice of the $5^{\circ} \mathrm{C}$ isotherm as the appropriate lower boundary of Atlantic water. The effect of isotherm depth variations is discussed in Part 6.2. Here, we use a fixed lower boundary given by the average $5{ }^{\circ} \mathrm{C}$ isotherm (Table 2).

For water colder than $5^{\circ} \mathrm{C}$, the calculations indicate a net flow of $2.3 \mathrm{~Sv}$ south-westward (Table 5a). This water feeds the overflows through the Faroe Bank Channel (2.0 Sv overflow; Hansen and Østerhus, 2007) and across the Wyville Thomson Ridge ( 0.2 to $0.3 \mathrm{~Sv}$ overflow; Sherwin et al., 2008a) and our calculations are in fair agreement with the combined, independently determined overflow estimates 


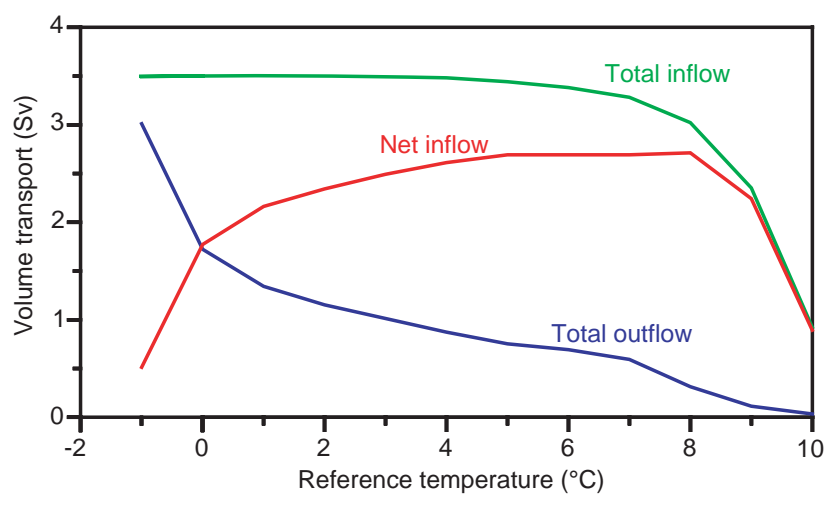

Fig. 7. The volume transport (using core interpolation) through the section of water warmer than a specified reference temperature plotted against the reference temperature. Total inflow (towards the Norwegian Sea) and total outflow (from the Norwegian Sea) volume transports are shown separately as well as their difference (net inflow).

through these passages. This adds confidence to the calculations for the Atlantic water transport.

The amount of salt carried by the Atlantic inflow (termed the salt transport) was calculated by multiplying the alongchannel velocity by the salinity for each depth and station pair during the integration and scaling the result to convert the values to total salt content. Heat transport is only well defined for a closed system, but most of the Atlantic inflow will leave the Arctic Mediterranean with temperatures close to zero. We can therefore compute heat transport relative to $0^{\circ} \mathrm{C}$ by multiplying the along-channel velocity by the temperature (in ${ }^{\circ} \mathrm{C}$ ) for each depth and station pair during the integration and multiplying the result by the specific heat $\left(\right.$ per $\left.\mathrm{m}^{3}\right)$. The quantities were calculated for water warmer than $5^{\circ} \mathrm{C}$ (Table 5a). On average, the north-eastward heat transport relative to $0^{\circ} \mathrm{C}$ equals $131 \mathrm{TW}$, but a transport of $24 \mathrm{TW}$ directed to the Atlantic means the Shetland Branch contributes a net heat transport of 107 TW to the Nordic seas. Similarly, the net salt transport by the Atlantic inflow equals $98 \times 10^{6} \mathrm{~kg} \mathrm{~s}^{-1}$, which is the sum of a north-eastward transport of $125 \times 10^{6} \mathrm{~kg} \mathrm{~s}^{-1}$ and a south-westward transport of $27 \times 10^{6} \mathrm{~kg} \mathrm{~s}^{-1}$. Uncertainty estimates of volume transport suggest both values have relative uncertainties of $\pm 20 \%$.

\section{Temporal variations of Atlantic water transport}

Altimetry-adjusted AW-velocities and geostrophic profiles may be combined to calculate a time-mean transport, but in order to extend these to month-to-month variations, we attempt two alternative approaches: one based solely on the ADCP data, the other on the altimetry data, calibrated with CTD and ADCP observations. Nevertheless, both estimates are not fully independent of each other, as the ADCP data was used to reference the geostrophic profiles and the al-
Table 5a. Average volume, heat (relative to $0^{\circ} \mathrm{C}$ ) and salt transports (positive towards the Norwegian Sea) through the FSC towards northeast (NE, positive) and southwest (SW, negative), as well as their difference (net) averaged over the 1995-2009 period (all using core interpolation scheme). All transports are based on geostrophic profiles (see text) and calculated from standard station 3 at the Faroese shelf edge to station 15 at $150 \mathrm{~m}$ bottom depth on the Shetland side. Transports of relative heat and salt were calculated only for the Atlantic water (i.e. warmer than $5^{\circ} \mathrm{C}$ ).

\begin{tabular}{lccr}
\hline & NE & SW & $\begin{array}{r}\text { Net } \\
\text { (Atl. Inflow) }\end{array}$ \\
\hline Surface-to-bottom $(\mathrm{Sv})$ & 3.5 & -3.1 & 0.4 \\
Warmer than $5^{\circ} \mathrm{C}(\mathrm{Sv})$ & 3.5 & -0.8 & 2.7 \\
Colder than $5^{\circ} \mathrm{C}(\mathrm{Sv})$ & 0.0 & -2.3 & -2.3 \\
\hline Relative Heat Transport $(\mathrm{TW})$ & 131 & -24 & 107 \\
Salt Transport $\left(10^{6} \mathrm{~kg} \mathrm{~s}^{-1}\right)$ & 125 & -27 & 98 \\
\hline
\end{tabular}

timetry velocities were used to set boundary conditions on the ADCP velocity integration.

\subsection{Transport variations based on ADCP data}

The ADCP data set has a number of gaps due to servicing and instrument failure. At site A, the flow is weak (Table 4) and the data from this mooring do not affect transport values very much; but sensitivity studies have shown that omission of some of the other ADCP sites may introduce large biases. In this study, we therefore only present results from periods when there was acceptable data from ADCP sites C, D, and $\mathrm{E}$ and from either $\mathrm{B}$ or $\mathrm{X}$.

A time series of transport was produced based only on the monthly mean along-channel velocity profiles (observed by ADCP at each site). Since we do not have continuous temperature measurements, we chose to integrate down to the average depth of the $5{ }^{\circ} \mathrm{C}$ isotherm for the deep sites, or to the sea bed at the shallower sites. The isotherm depths at each site (Table 1) were determined by interpolation from Table 2 . Following Sherwin et al. (2008b), the transport density $(\Psi)$ in $\mathrm{m}^{2} \mathrm{~s}^{-1}$ was calculated at each site by taking the sum of the velocity $v$ multiplied by the size of the depth bin $(25 \mathrm{~m})$ down to these depths.

$\Psi=\sum_{d}\left(v_{d} \cdot 25 \mathrm{~m}\right)$

To calculate the volume transport, each ADCP, $j$, is assigned a width $L_{j}$ (extending on both sides to the midpoints between neighbouring ADCPs), when sufficient moorings have been deployed. The two endpoints of the section (equivalent to stations 3 and 15 on the section) are assumed to have constant velocities. Similar to the adjustment of the geostrophic profiles, these endpoints have been assigned the time-mean altimetry-adjusted AW-velocities at ADCP sites $\mathrm{A}$ and $\mathrm{F}$ 
Table 5b. Historic estimates of the net volume transport of Atlantic water through the FSC.

\begin{tabular}{|c|c|c|}
\hline Author & $\begin{array}{l}\text { Net volume } \\
\text { transport of } \\
\text { Atlantic water }\end{array}$ & Method \\
\hline Tait (1957) & $2.3 \mathrm{~Sv}$ & Based on geostrophy, AW defined as $S=35.0$ \\
\hline Dooley and Meincke (1981) & $2.0 \mathrm{~Sv}$ & Based on geostrophy with a level of no motion at $550 \mathrm{~m}$. \\
\hline Gould et al. (1985) & $7.5 \mathrm{~Sv}$ & Single-point current meter moorings across the Shetland slope. \\
\hline van Aken (1988) & $\sim 2.0 \mathrm{~Sv}$ & Inverse method based on mass conservation, AW defined as $\sigma_{t}<27.8 \mathrm{~kg} \mathrm{~m}^{-3}$. \\
\hline $\begin{array}{l}\text { Schlichtholz and Jankowski } \\
\text { (1993) }\end{array}$ & $0.99-1.82 \mathrm{~Sv}$ & $\begin{array}{l}\text { Inverse method based on mass conservation; their definition }\left(\sigma_{t}<27.82 \mathrm{~kg} \mathrm{~m}^{-3}\right) \\
\text { includes intermediate water masses. }\end{array}$ \\
\hline Turrell et al. (1999a) & $3.2 \mathrm{~Sv}$ & $\begin{array}{l}\text { Interpolation of ADCP and CTD observations across the FSC and in time, AW } \\
\text { defined by a 3-point mixing model. }\end{array}$ \\
\hline Hughes et al. (2006) & $3.9 \mathrm{~Sv}$ & Same as above. \\
\hline Sherwin et al. (2008b) & $3.5 \mathrm{~Sv}$ & ADCP-based transport (with associated widths), AW defined as surface $500 \mathrm{~m}$. \\
\hline Rossby and Flagg (2012) & $1.5 \mathrm{~Sv}$ & Vessel-mount ADCP observations, AW defined as $\sigma_{t}<27.8 \mathrm{~kg} \mathrm{~m}^{-3}$ \\
\hline
\end{tabular}

(Column 6 in Table 4). The endpoint criteria are needed for the integration process, and as the observed speeds are relatively weak, but greater than zero, the choice of the timemean altimetry adjusted AW-velocities means the integration estimates the Atlantic inflow more representatively. The monthly mean transport $Q(t)$ for each month $t$, also termed the $A D C P$ transport, is then calculated by taking the sum across the channel of the transport density multiplied by the width (see Table 1):

$Q(t)=\sum_{j}\left(\Psi_{j} \cdot L_{j}\right)$.

During the first period of ADCP deployments (November 1994 to May 2009, Fig. 3b), the ADCP transport was calculated for all months with at least 28 days of data at sites B, C, D, and E. Between May 2009 and May 2011, additional ADCPs were deployed on the section, and sites $\mathrm{X}, \mathrm{Y}$, C, G, D, E, and F were instrumented (see Figs. 2 and 3, and Table 1), whereas site B was abandoned. Gaps in observations in this latter period arise due to instrument failures and mooring losses at sites X and D (Fig. 3b).

The time series of ADCP transport is shown in Fig. 8. The average volume transport for the whole period is $3.1 \mathrm{~Sv}$ with a standard deviation of the monthly observations of 1.2 Sv. When the observations are plotted by month (Fig. 9), we observe seasonality in the ADCP transport, although it is masked by the large variability. We further investigated this by fitting a sinusoidal harmonic with a periodicity of 12 months using a least squares method (Emery and Thomson, 1997). The fitted harmonic (solid red line in Fig. 9) has an amplitude of $0.9 \mathrm{~Sv}$ with a maximum in November. The statistical fit has an $R^{2}$ of 0.21 (21\% of the variability is explained by seasonal variations). This result agrees with the seasonality found for the mean velocity in the upper layer, as previously discussed above and presented in Table 3 . Within the region, Hansen et al. (2010) found no strong evidence of seasonality in the Atlantic inflow north of the Faroe Islands, while the analysis by Mork and Skagseth (2010) showed a maximum in the Atlantic inflow observed on the Svinoy section in winter which agrees with our results. Regression analysis of the residuals from the seasonal analysis against time shows no statistically significant long-term trend in the observed ADCP transport (Table 6).

\subsection{Transport variations based on altimetry data}

Although we can link sea level differences to the surface velocities through geostrophy, we also need to know velocities at depth in order to calculate volume transport. In the following section, we argue the possibility of establishing this link, and use it to estimate volume transport based on altimetry data.

The altimetry points $\mathrm{a} 0$ and a 6 are close to the ends of the section, and can be used to define a time series of sea level difference across the section $(\Delta h(t)=\mathrm{a} 6-\mathrm{a} 0)$. To link this sea level difference to volume transport, we assume that (1) the vertically averaged (but time-varying) velocity of the Atlantic water layer is proportional to the surface velocity, and (2) the product of this proportionality and the depth of the Atlantic water layer is constant along the section $(\alpha(x) D(x)=\langle\alpha D\rangle)$. We will discuss both these assumptions in more detail, and justify their application to the section. Mathematically, they can be written as

$$
\begin{aligned}
Q(t) & =\iint_{-D(x)}^{0} v(x, z, t) \mathrm{d} z \mathrm{~d} x \cong \int \alpha(x) D(x) v(x, 0, t) \mathrm{d} x \\
& \cong \frac{g}{f}\langle\alpha D\rangle \int \frac{\partial h}{\partial x} \mathrm{~d} x,
\end{aligned}
$$

where $v(x, z, t)$ is the along-channel velocity at horizontal location $x$ (along the section), vertical location $z$ and time $t$ and $D(x)$ the depth to which we integrate at each location on the section. $h(x, t)$ is the absolute sea level along the section. 
Table 6. Results of trend analyses for volume transport calculated from the ADCP observations and from Altimetry. The third column shows the trend determined by linear regression of the residual from a seasonal sinusoidal fit of volume transport on time and the fourth column its $95 \%$ confidence interval assuming no serial correlation.

\begin{tabular}{llll}
\hline Time series & Period & $\begin{array}{l}\text { Trend } \\
\mathrm{Sv} \mathrm{yr}^{-1}\end{array}$ & $\begin{array}{l}\text { Conf. Int. } \\
\mathrm{Sv} \mathrm{yr}^{-1}\end{array}$ \\
\hline ADCP transport & Oct 1998-Apr 2011 & -0.055 & 0.085 \\
Altimetry transport & Dec 1992-Sep 2011 & -0.006 & 0.019 \\
\hline
\end{tabular}

The parameter $\alpha(x)$ is a site-dependent proportionality factor.

The last integral in Eq. (3) is equal to $\Delta h(t)$, and this equation therefore becomes

$Q(t)=Q_{0}+\beta \times \Delta h(t)$

with $\beta \equiv g\langle\alpha D\rangle / f$ and $Q_{0}$ is a constant, which corrects for any differences between absolute sea level and the altimetry data.

Our first assumption (the vertically average velocity at location $x$ is proportional to the surface velocity) may be evaluated using the ADCP observations (see also Fig. 5). We estimated $\alpha$ at each site (Table 7) using a linear regression (modified to go through the origin). $R^{2}$-values exceed 0.93 , except for site A, which has weak flows. This justifies the first approximation in Eq. (3):

$$
\frac{1}{D(x)} \int_{-D(x)}^{0} v(x, z, t) \mathrm{d} z \cong \alpha(x) v(x, 0, t) .
$$

The second assumption (the product $\alpha D$ is constant along the section) is less robust: partly due to variations in $\alpha(x)$ (Table 7), and partly due to variations in the lower boundary of the integration, $D(x)$, which equals the average depth of the $5{ }^{\circ} \mathrm{C}$ isotherm except in the shallow regions at the ends of the section (consistent with the ADCP transport calculation above).

Most of the volume transport and the associated sea level changes are localised in the inflow core between ADCP sites $\mathrm{G}, \mathrm{D}$, and $\mathrm{E}$ and in the outflow core close to $\mathrm{X}$ (Fig. 6). We obtain a rough estimate of the empirical value for $\beta$ by averaging the last column of Table 7 for these four ADCP sites: $\beta=0.29 \mathrm{~Sv} \mathrm{~cm}^{-1}$. From the variations in Table 7 and the above arguments, we would expect an uncertainty of the order of $20 \%$.

Alternatively, we may determine $\beta$ from a linear regression between the ADCP transport and the $\Delta h$ time series. We find $\beta$ equals $0.22 \pm 0.11 \mathrm{~Sv} \mathrm{~cm}^{-1}$ with a $95 \%$ confidence limit, and a correlation coefficient equal to 0.47 . The empirical value for $\beta$ is higher than this value from regression analysis, but falls within the confidence limits. As the calculation of the ADCP transport includes an additional set of approximations, we will use the empirical value: $\beta=0.29 \mathrm{~Sv} \mathrm{~cm}^{-1}$.
Table 7. Relationship between average (surface to $5^{\circ} \mathrm{C}$ isotherm or bottom) and surface along-channel velocity for the various ADCP sites. The parameter $\alpha$ is determined by linear regression through the origin and $R^{2}$ is the goodness of fit. The last column lists the empirical proportionality factor between transport and sea level difference at each site according to Eq. (3).

\begin{tabular}{ccccc}
\hline Site & Months & $\alpha$ & $R^{2}$ & $\begin{array}{c}\beta=g D \alpha / f \\
\mathrm{~Sv} \mathrm{~cm}^{-1}\end{array}$ \\
\hline A & 37 & 0.780 & 0.665 & 0.178 \\
X & 12 & 1.017 & 0.943 & 0.306 \\
B & 131 & 0.812 & 0.970 & 0.243 \\
Y & 20 & 0.872 & 0.976 & 0.268 \\
C & 157 & 0.843 & 0.937 & 0.275 \\
G & 19 & 0.770 & 0.950 & 0.273 \\
D & 156 & 0.754 & 0.963 & 0.293 \\
E & 179 & 0.796 & 0.987 & 0.275 \\
F & 11 & 1.017 & 0.990 & 0.135 \\
\hline
\end{tabular}

We can now calculate the Altimetry transport, for the net inflow of Atlantic water through the FSC, based on the $\Delta h$ time series. The value of $Q_{0}$ is adjusted such that the average value for 1995-2009 equals $2.7 \mathrm{~Sv}$ (the average volume transport calculated in Part 4, see also Table 5). This constant incorporates the mean transport, the time-mean of the errors and the influence of the geoid on the section, and has a value of $2.49 \mathrm{~Sv}$. The analysis is now independent of absolute sea level based on an accurate geoid. The value chosen for $\beta$ only affects the variability of the Altimetry transport, not its mean value. When considering long-term change in the volume transport, this would mean that any trend estimated from a linear regression on time would be proportional to $\beta$, as would its confidence interval be, hence the statistical significance of the trend would be unaffected.

The Altimetry transport has less variance than the ADCP transport with a standard deviation of $0.9 \mathrm{~Sv}$, as can also be seen when these time series are plotted together in Fig. 8. The Altimetry transport has a seasonal amplitude of $0.7 \mathrm{~Sv}$, with a maximum in January $\left(R^{2}=0.31\right.$; black dotted line curve in Fig. 9). The Altimetry transport does not exhibit any statistically significant trend (Table 6).

\section{Discussion}

\subsection{The flow through the FSC}

As shown in Fig. 1, some of the Atlantic inflow from the Faroe Branch (FB) turns into the FSC to flow southwestwards along the Faroese side of the FSC. HellandHansen and Nansen (1909) first proposed this current, and it was later termed the "Southern Faroe Current" by Hátún (2004). Drifter tracks show that at least a part of this flow recirculates within the channel (Hátún, 2004), turning counterclockwise to join the inflow from the west. Based on drifter 


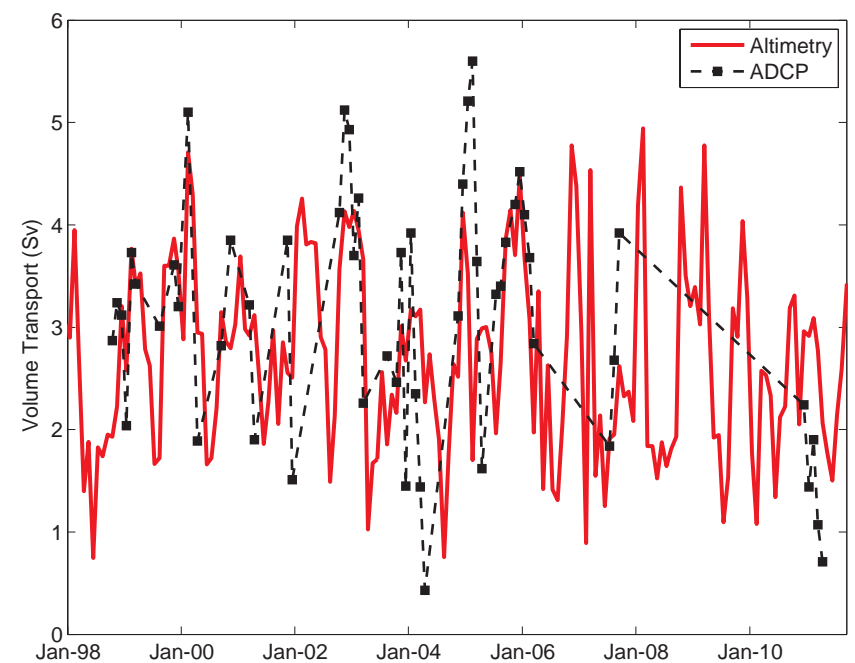

Fig. 8. Monthly mean net volume transport above the $5{ }^{\circ} \mathrm{C}$ isotherm through the FSC. Black rectangles connected with a dashed line show the ADCP transport. The red curve shows the Altimetry transport.

observations, Sherwin et al. (2006) estimated the volume transport of the Southern Faroe Current to be 2.0 Sv. Dooley and Meincke (1981) suggested that a substantial part of this flow may continue westwards into the Faroe Bank Channel, and Rossby and Flagg (2012) proposed that the current circulates around the Faroe Plateau.

The Southern Faroe Current - seen in the average velocity distribution on the section as an outflow in the upper layers on the Faroe side of the channel (Fig. 4) - has an average volume transport of Atlantic water (i.e. water warmer than $5^{\circ} \mathrm{C}$ ) of $-0.8 \mathrm{~Sv}$. This is weaker than the previous estimate by Sherwin et al. (2006), but it should be noted that their estimate was made further north in the FSC, and thus much of the recirculation may already have occurred at the point where the Southern Faroe Current is observed on the FIM section.

From our observations, we are unable to state unequivocally how much of the Southern Faroe Current recirculates within the FSC, or what its pathway is if it does not recirculate and we therefore will not address this question further. Chafik (2012) recently showed that the dynamics of the Continental Slope Current and MNAW recirculation in the FSC are related to NAO state and circulation in the Norwegian Sea. For our study, we consider the flow through the sections (Fig. 4) as three components: (1) an inflow of Atlantic water over the Shetland side, (2) an outflow of Atlantic water in the upper layers over the Faroe side, and (3) a deep cold outflow feeding the overflows. In this study, we focus on the difference between (1) and (2), which is the net inflow of Atlantic water through the channel.

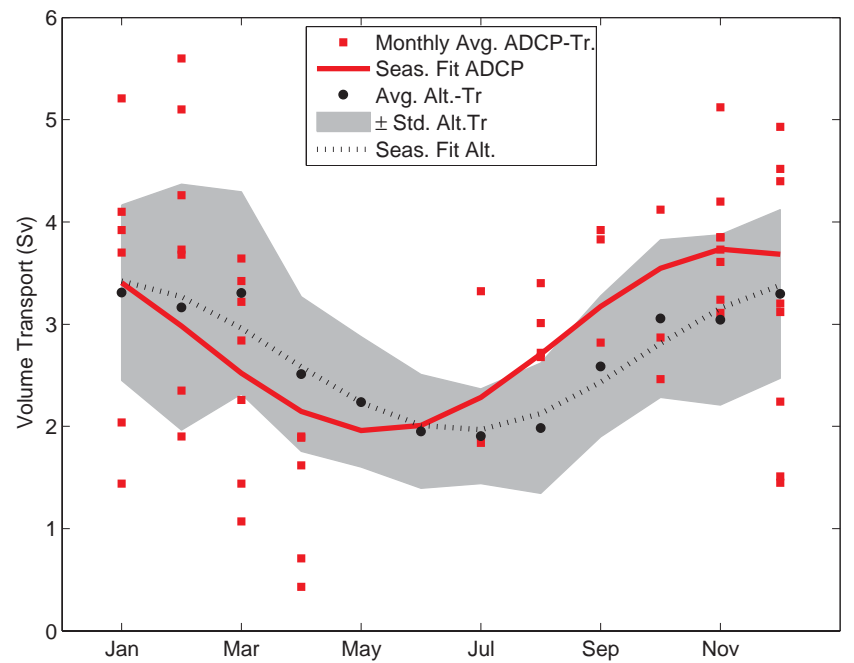

Fig. 9. Monthly mean net volume transport above the $5^{\circ} \mathrm{C}$ isotherm through the FSC plotted against month. Red rectangles indicate individual monthly mean ADCP transport, solid red line shows sinusoidal fit for this data $\left(R^{2}=0.21\right)$. Black circles indicate average transport for each month based on the full Altimetry transport series, and the grey area surrounding it indicates \pm the standard deviation. The dotted black line shows the best sinusoidal fit to the full Altimetry-transport series $\left(R^{2}=0.30\right)$.

\subsection{Average volume, heat, and salt transport}

We combined altimetry-adjusted velocities and geostrophic profiles to provide a best estimate of the volume transport of Atlantic water through the channel (discussed in Part 4). We found that the average net inflow between 1995 and 2009 of Atlantic water was $2.7 \mathrm{~Sv}$.

These calculations were based on a fixed lower boundary of the Atlantic water, as defined by the average depth of the $5^{\circ} \mathrm{C}$ isotherm. In reality, this isotherm varies considerably in depth (Table 2), but is known only for the times of CTD cruises. Since some of the variation may be linked to the velocity field and hence to sea level, we have regressed the $5^{\circ} \mathrm{C}$ isotherm depth as determined from each of the cruises on SLH differences between altimetry points using weekly averaged data from the week including the cruise. For the midchannel CTD stations, 7 and 8, the regression could explain more than $60 \%$ of the variance, but this not the case close to the Faroe Shelf where the correlation is much weaker (CTD station 4). Using the regression coefficients, the variations of isotherm depth can be simulated for the whole altimetry period and the effect of these variations on the vertically integrated velocity can be estimated for each of the three longterm ADCP sites B, C, and D. For the average volume transport of Atlantic water, discussed in Part 4, the most likely effect would be a slight increase, on the order of $0.1 \mathrm{~Sv}$, but the uncertainty is more than that. For the time series of annually averaged volume transport (Fig. 10), variations in the $5^{\circ} \mathrm{C}$ isotherm depth could induce changes of a few tenths of a 
Sverdrup, but again with large uncertainties. There is no indication that this would induce a long-term trend in the volume transport.

Our study is the first to combine ADCP observations and geostrophic velocities across the FSC with altimetry data. Previous estimates of the net volume transport of Atlantic water through the FSC range between 1.5 and $3.9 \mathrm{~Sv}$ (Table 5b). Two estimates have not been included in this range: the estimate by Gould et al. (1985) considered only the Continental Slope Current and that of Schlichtholz and Jankowski (1993) included a considerable amount of intermediate water transport due to their choice of the $3{ }^{\circ} \mathrm{C}$ isotherm. Compared to comparable ADCP-based values, our estimate is low, but recently, Rossby and Flagg (2012) presented a net inflow estimate of approximately $1.5 \mathrm{~Sv}$ (for water less dense than $1027.8 \mathrm{~kg} \mathrm{~m}^{-3}$ between the shelf edges), based on vessel mounted ADCP data.

The Shetland branch has been considered the strongest of the three inflow branches (Fig. 1) in terms of volume transport, as well as heat and salt transport (Østerhus et al., 2005), but our new estimate suggests the Faroe branch is stronger with a volume transport of $3.5 \mathrm{~Sv}$ for the period 1997 to 2008 (Hansen et al., 2010). Adding 0.8 Sv for the Iceland branch (Jónsson and Valdimarsson, 2012), the total Atlantic inflow becomes $7.0 \mathrm{~Sv}$, on the average; rather than $8.5 \mathrm{~Sv}$ reported by Østerhus et al. (2005) for the period 1999-2001. This lower value puts additional constraints on transport values for the outflows when the total mass budget for the Arctic Mediterranean is considered; especially the overflow across the Iceland-Faroe Ridge, the Canadian Archipelago outflow and the East Greenland Current. Recently, Mork and Skagseth (2010) combined altimetry and hydrography for the Norwegian Atlantic Current, and estimated its mean volume transport to be $5.1 \mathrm{~Sv}$. These estimates are in reasonable agreement with those of the combined Atlantic inflow presented here, considering expected errors, as well as the circulation of Atlantic water into the North Sea and exchange into the interior of the Norwegian Basin.

We find the net relative (to $0^{\circ} \mathrm{C}$ ) heat transport to be $107 \mathrm{TW}\left(1 \mathrm{TW}=10^{12} \mathrm{~W}\right)$ and the net salt transport to be $98 \times 10^{6} \mathrm{~kg} \mathrm{~s}^{-1} \pm 20 \%$ for the $1995-2009$ period (Table 5a). Holliday et al. (2000) previously estimated the climatological mean transport of heat and salt (1975-1998) of the transport above $1200 \mathrm{dbar}$ in the Rockall Trough. Their estimates of $130 \mathrm{TW}$ and $123.8 \times 10^{6} \mathrm{~kg} \mathrm{~s}^{-1}$ for the transport of heat and salt respectively, are in reasonable agreement with those presented here.

We can find values of the transport-averaged temperature and salinity, by dividing these values by the average net volume transport and scaling. Dividing the north-eastward heat and salt transports by the north-eastward volume transport, we find that the inflow over the Shetland side has an average temperature of $9.25^{\circ} \mathrm{C}$ and average salinity of 35.33. Part of this water has come directly from the west into the FSC, but some fraction, $\gamma$, may have recirculated in the channel. With the notation indicated in Fig. 2, the average net heat transport $P_{\text {net }}$ may be written

$$
\begin{aligned}
P_{\text {net }} & =P_{\text {in }}-P_{\text {out }}=c\left(Q_{\text {in }} T_{\text {in }}-Q_{\text {out }} T_{\text {out }}\right) \\
& =c\left(Q_{\mathrm{W}} T_{\mathrm{W}}+\gamma Q_{\text {out }} T_{\text {out }}-Q_{\text {out }} T_{\text {out }}\right)
\end{aligned}
$$

where $c$ is specific heat (per volume) and $Q_{\mathrm{W}}$ is the volume transport of water entering the FSC from the west (Fig. 2), equal to $Q_{\text {in }}-\gamma Q_{\text {out }}$. If, as suggested by Hansen and Østerhus (2000), all the outflowing water warmer than $5{ }^{\circ} \mathrm{C}\left(Q_{\text {out }}\right)$ is recirculated within the $\operatorname{FSC}(\gamma=1)$ without any exchanges of heat or freshwater with the atmosphere or deeper layers, we find the temperature of the water coming from the west: $T_{\mathrm{W}}=P_{\text {net }} /\left(c Q_{\text {net }}\right)=9.7^{\circ} \mathrm{C}$, and similarly for its salinity: $S_{\mathrm{W}}=35.36$.

\subsection{Comparison of the two transport time series}

We have presented two different time series of monthly averaged net Atlantic water flow through the FSC: ADCP transport and Altimetry transport. Although the ADCP transport series has a higher mean volume transport of Atlantic water, the two estimates agree within the uncertainty estimate. The correlation coefficient between these two transport series (0.49) is much lower than what may be expected from the relatively high correlations between altimetry and individual ADCP records (Table 4). The ADCP transport also has a higher standard deviation $(1.3 \mathrm{~Sv})$ than the Altimetry transport $(0.9 \mathrm{~Sv})$. This may be due to other physical processes contributing to the variability in the ADCP observations, which are not covered by the geostrophic assumption. There are also processes on spatial scales not resolved by the mooring array which may result in aliasing. Other methods may be used to interpolate and integrate the ADCP velocities to transport values than those expressed in Eqs. (1) and (2) such as interpolating velocity, rather than transport density but the high variance in the net inflow remains and likely derives from the variable flow structure within the channel. This may explain the higher mean value of the ADCP transport series and its higher standard deviation. Previous attempts to estimate volume transport from sea level differences between Tórshavn and Lerwick found similar issues with the complex circulation of the FSC (McClimans et al., 2003).

The Altimetry transport is based on measurements that integrate across the channel, as demonstrated by Eq. (3), and is therefore less sensitive to changes in the flow structure. Altimetry, however, only measures surface velocities directly, whereas the ADCPs sample most of the Atlantic water layer.

We may, however, expect the depth of the Atlantic layer to change with the strength of the inflow. With no significant trends in either the velocity field (Table 3), or the isotherm depth (Table 2) across the FSC, we do not consider this of influence when considering the long-term average or linear trend. This may be of importance when looking at monthly to seasonal variability, which we hope to further investigate using numerical simulations of the region. 


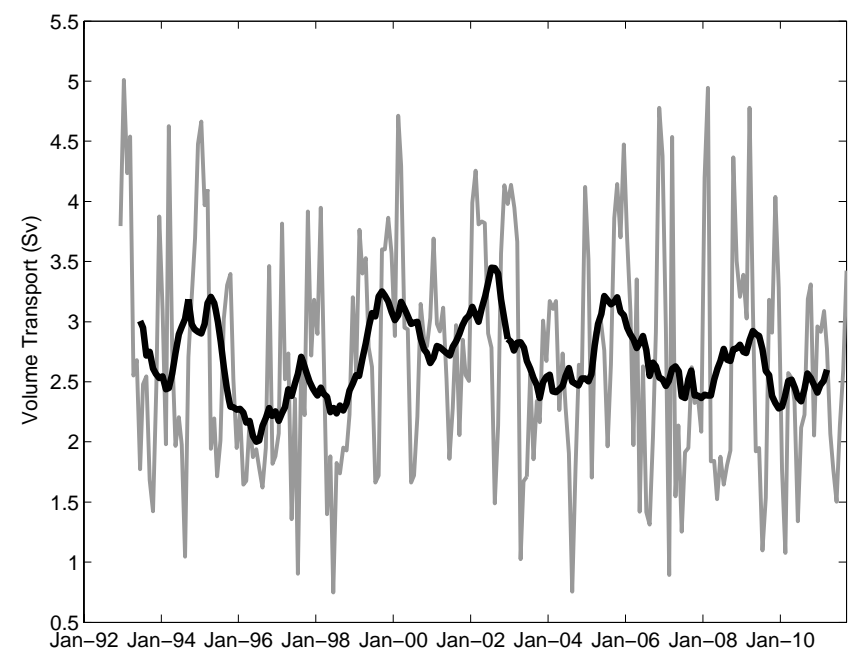

Fig. 10. Temporal variation of the Atlantic inflow through the FSC between the shelf edge on the Faroe side and $150 \mathrm{~m}$ depth on the Shetland side since December 1992, based on altimetry data calibrated by ADCP and CTD data. Thin grey line shows monthly mean, thick black line 12 month running mean.

Both time series (Altimetry transport and ADCP transport) have a certain level of uncertainty associated with them due to the underlying assumptions in their calculation and are not completely independent. While the ADCP transport series may alias spatial scales, it includes processes that are not covered by the assumption of geostrophy. The Altimetrytransport series does however allow us to estimate the volume transport of Atlantic water through the FSC at times when the ADCP array was incomplete or missing. We can therefore present a time series based on Altimetry from 1992 onwards, shown in Fig. 10.

\subsection{Seasonal variation}

Both the ADCP transport and the Altimetry-transport time series exhibit consistent seasonal variations although they are partly masked by other kinds of variability as demonstrated by the rather low $R^{2}$ values ( 0.21 and 0.30 , respectively). Both series indicated maximum transport around the turn of the year. With such low $R^{2}$ values, both the seasonal amplitude and the month of maximum transport will be somewhat uncertain. A Monte Carlo simulation indicates that the difference in time of maximum (November vs. January) for the two data sets is not statistically significant.

The seasonal amplitudes differ $(0.9 \mathrm{~Sv}$ for the ADCP transport and $0.7 \mathrm{~Sv}$ for the Altimetry transport), but this may be due to a higher noise level in the ADCP transport. Both estimates ignore seasonal variations in the hydrography, but CTD data indicate that the $5^{\circ} \mathrm{C}$ isotherm is deeper in autumn than in spring. Flows are weaker close to this lower boundary, and this variation has little influence on the seasonal amplitude of the volume transport. We therefore conclude that the seasonal amplitude of the net inflow likely is close to $0.7 \mathrm{~Sv}$, with maximum volume transport in winter. Previous estimates of the seasonality in the transport and currents in the region have highlighted a similar seasonality with the Atlantic inflow being stronger in winter months than summer (Sherwin et al., 2008b; Mork and Skagseth, 2010)

\subsection{Long-term trends}

On longer timescales, inter-annual variations on the order of $1 \mathrm{~Sv}$ are seen (Fig. 10), but the principal question is with respect to long-term trends. The Atlantic inflow is an integral part of the North Atlantic thermohaline circulation, which is predicted to weaken due to anthropogenic climate change (Bindoff et al., 2007). The temporal development of the Atlantic inflow through the FSC is therefore a question of great interest: "is there any indication that this flow is weakening?"

Linear trend analyses of the two transport series are summarised in Table 6 . The estimated trends are smaller than the $95 \%$ confidence intervals and thus not statistically significant. Both the ADCP transport and the Altimetry transport are integrated down to the sea bed or to the average depth of the $5^{\circ} \mathrm{C}$ isotherm. The horizontal variation of this isotherm was taken into account, but not its temporal variation. This may introduce additional variability to the transport time series (Fig. 10), but the available data do not allow us to quantify this variability. An analysis of the long-term trend in the $5^{\circ} \mathrm{C}$ isotherm depth indicates no significant changes during our observational period (Table 2). This supports the conclusion of a stable Atlantic inflow.

This apparent stability has also been reported for the other two Atlantic inflow branches (Hansen et al., 2010; Jónsson and Valdimarsson, 2012), as well as for the Faroe Bank Channel overflow (Hansen and Østerhus, 2007) and the Denmark Strait overflow (Jochumsen et al., 2012).

If the volume transport through the FSC did not change, while temperature and salinity of the inflowing water both increased from the mid-1990s (Table 2), then one might expect increasing heat and salt transport. The uncertainty introduced by the high transport variability means we are unable to provide a conclusive statement on the trend in relative heat or salt transport.

\section{Summary and outlook}

By combining ADCP, CTD and altimetry data from the 1995-2009 period, we estimate the average net inflow of Atlantic water (warmer than $5^{\circ} \mathrm{C}$ ) through the FSC to $2.7 \pm 0.5 \mathrm{~Sv}$. The average heat transport relative to $0^{\circ} \mathrm{C}$ was estimated to $107 \pm 21 \mathrm{TW}$ and the average salt import to $98 \pm 20 \times 10^{6} \mathrm{~kg} \mathrm{~s}^{-1}$. Although highly variable, the net volume transport seems to have a consistent seasonality with maximum flow around the turn of the year and a seasonal amplitude of $0.7 \mathrm{~Sv}$. We find no significant trend in the volume 
transport between December 1992 and September 2011, but increasing temperatures and salinities may have induced positive trends in the relative heat and salt transports, although this is difficult to verify statistically.

When the ADCP mooring system was designed in the early 1990s, it was decided to locate the ADCPs on a section that had been monitored for temperature and salinity for more than a century. As the measurements progressed, it became clear that the high variability on that section would make short-term transport variations difficult to monitor with the established system.

The comprehensive ADCP and CTD data set has allowed us to calibrate altimetry data to provide volume transport time series and, for the future, altimetry data will be an essential component of a monitoring system, but continued in situ measurements will be needed to monitor water mass properties and the subsurface velocity field. Whether this monitoring should remain on the established section (Fair IsleMunken), or be moved to a section farther southwest depends on results from an experiment carried out in 20112012 within the EU-funded THOR project and on on-going measurements in the framework of EU-NACLIM.

Acknowledgements. We would like to thank Detlef Quadfasel, Hjálmar Hátún and Steffen Olsen for constructive feedback during the preparation of this manuscript. We also acknowledge the assistance of the staff and students with the collection of CTD and ADCP data in the FSC; in particular George Slesser, Dougal Lichtman, John Beaton, Matt Geldart, Bill Turrell and Sarah Hughes at MSS, and Regin Kristiansen and Ebba V. Mortensen at FAMRI. Data were collected during cruises on FRV Scotia and R/V Magnus Heinason, these data would not be available without the dedication of all the officers and crew onboard these vessels. ADCP data collected by oil operators were used with the permission and collaboration from the North West Approaches Group (NWAG); these data were archived and supplied by Fugro GEOS.

ADCP and CTD data collection between 1994 and 2011 have been partly funded by the following projects: NWOCE (Nordic WOCE; Nordic Council), VEINS (Variability of Exchanges in the Northern Seas; EU Contract Nr. MAST-III MAS3960070), MAIA (Monitoring the Atlantic Inflow towards the Arctic; EU Contract Nr. EVK2-CT-1999-00008), MOEN (Meridional Overturning Exchange with the Nordic seas; EU Contract Nr. EVK2-CT-2002000141), and THOR (Thermohaline Overturning - at Risk?; EU Grant Nr. 212643). This work has also been supported by NAACOS and DANCEA, which are programs under the Danish government. The research leading to this publication has received funding from the European Union 7th Framework Programme (FP7 2007-2013) under grant agreement n. 308299 NACLIM Project.

Edited by: D. Stevens

\section{References}

Bindoff, N. L., Willebrand, J., Artale, A., Cazenave, A., Gregory, J., Gulev, S., Hanawa, K., Le Quere, C., Levitus, S., Nojiri, Y., Shum, C. K., Talley, L. D., and Unnikrishnan, A.: Observations: Oceanic Climate Change and Sea Level, in: Climate Change 2007: The Physical Science Basis. Contribution of Working Group 1 to the Fourth Assessment Report of the Intergovernmental Panel on Climate Change., edited by: Solomon, S., Qin, D., Manning, M., Chen, Z., Marquis, M., Averyt, K. B., Tignor, M., and Miller, H. L., Cambridge University Press, 385-432, 2007.

Blindheim, J.: Arctic intermediate water in the Norwegian Sea, Deep-Sea Res., 37, 1475-1489, 1990.

Chafik, L.: The response of the circulation in the Faroe-Shetland Channel to the North Atlantic Oscillation, Tellus A, 64, 18423, doi:10.3402/tellusa.v64i0.18423, 2012.

Dickson, R. R., Gould, W. J., Griffiths, C. R., Medler, K. J., and Gmitrowitcz, E. M.: Seasonality in currents of the Rockall Channel, P. Roy. Soc. Edinb. B, 88, 103-125, 1986.

Dooley, H. D. and Meincke, J.: Circulation and water masses in the Faroese Channels during Overflow '73, Deutsche Hydrographische Zeitschrift, 34, 41-54, 1981.

Durbin, J. and Watson, G. S.: Testing for Serial Correlation in Least Squares Regression. II, Biometrika, 38, 159-178, 10.1093/biomet/38.1-2.159, 1951.

Emery, W. J. and Thomson, R. E.: Data Analysis Methods in Physical Oceanography, 1st Edn., Pergamon, 1997.

Godin, G.: The analysis of tides, Liverpool University Press, Liverpool, 1968.

Gould, W. J., Loynes, J., and Backhaus, J. O.: Seasonality in slope current transports NW of Shetland, ICES CM1985/C:7, 1985.

Hall, R. A., Huthnance, J. M., and Williams, R. G.: Internal tides, nonlinear internal wave trains, and mixing in the Faroe-Shetland Channel, J. Geophys. Res., 116, C03008, doi:10.1029/2010jc006213, 2011.

Hansen, B. and Østerhus, S.: North Atlantic - Nordic Seas Exchanges, Progr. Oceanogr., 45, 109-208, 2000.

Hansen, B. and Østerhus, S.: Faroe Bank Channel overflow 1995-2005, Progr. Oceanogr., 75, 817-856, doi:10.1016/j.pocean.2007.09.004, 2007.

Hansen, B., Hátún, H., Kristiansen, R., Olsen, S. M., and Østerhus, S.: Stability and forcing of the Iceland-Faroe inflow of water, heat, and salt to the Arctic, Ocean Sci., 6, 1013-1026, doi:10.5194/os-6-1013-2010, 2010.

Hátún, H.: The Faroe current, Ph.D., University of Bergen, 2004.

Helland-Hansen, B. and Nansen, F.: The Norwegian Sea, Fiskeridir. Skr. Ser. Havunders., 2, 1-390, 1909.

Holliday, N. P., Pollard, R. T., Read, J. F., and Leach, H.: Water mass properties and fluxes in the Rockall Trough, 1975-1998, Deep-Sea Res. Pt. I, 47, 1303-1332, 2000.

Holliday, N. P., Hughes, S. L., Bacon, S., Beszczynska-Möller, A., Hansen, B., Lavín, A., Loeng, H., Mork, K. A., Østerhus, S., Sherwin, T., and Walczowski, W.: Reversal of the 1960s to 1990s freshening trend in the northeast North Atlantic and Nordic Seas, Geophys. Res. Lett., 35, L03614, doi:10.1029/2007GL032675, 2008.

Hughes, S. L. and Turrell, W. R.: The Slope Current on the Shetland Shelf of the Faroe Shetland Channel - Statistics and Trends -, ICES CM2004/N:08, 2004. 
Hughes, S. L., Turrell, W. R., Hansen, B., and Østerhus, S.: Fluxes of Atlantic Water (Volume, Heat and Salt) in the Faroe-Shetland Channel calculated from a decade of Acoustic Doppler Current Profiler data (1994-2005), http://www.scotland.gov.uk/Uploads/ Documents/Coll0106.pdf, 2006.

Hughes, S. L., Holliday, N. P., and Beszczynska-Möller, A.: The ICES Report on Ocean Climate 2010, 309-369, 2011.

Jochumsen, K., Quadfasel, D., Valdimarsson, H., and Jónsson, S.: Variability of the Denmark Strait overflow: moored time series from 1996-2011, J. Geophys. Res., 117, C12003, doi:10.1029/2012JC008244, 2012.

Jónsson, S. and Valdimarsson, H.: Water mass transport variability to the North Icelandic shelf, 1994-2010, ICES J. Mar. Sci., 69, 809-815, doi:10.1093/icesjms/fss024, 2012.

Larsen, K. M. H., Hansen, B., and Svendsen, H.: Faroe Shelf Water, Cont. Shelf Res., 28, 1754-1768, 2008.

Larsen, K. M. H., Hátún, H., Hansen, B., and Kristiansen, R.: Atlantic water in the Faroe area: sources and variability, ICES J. Mar. Sci., 69, 802-808, doi:10.1093/icesjms/fss028, 2012.

Lehodey, P., Alheit, J., Barange, M., Baumgartner, T., Beaugrand, G., Drinkwater, K., Fromentin, J.-M., Hare, S. R., Ottersen, G., Perry, R. I., Roy, C., van der Lingen, C. D., and Werner, F.: Climate Variability, Fish and Fisheries, J. Climate, 19, 5009-5030, 2006.

McClimans, T. A., Hansen, B., Hátún, H., Huthnance, J. M., Loeng, H., Ingvaldsen, R., and Watson, A.: MAIA WP 7 Report: Validation and recommendations, 2003.

Mork, K. A. and Skagseth, Ø.: A quantitative description of the Norwegian Atlantic Current by combining altimetry and hydrography, Ocean Sci., 6, 901-911, doi:10.5194/os-6-901-2010, 2010.

Østerhus, S., Turrell, W. R., Johnsen, S., and Hansen, B.: Measured volume, heat and salt fluxes from the Atlantic to the Arctic Mediterranean, Geophys. Res. Lett., 32, L07603, doi:10.1029/2004GL022188, 2005.

Read, J. F. and Pollard, R. T.: Water masses in the region of the Iceland-Faroe Front, J. Phys. Oceanogr., 22, 1365-1378, 1992.

Rossby, T. and Flagg, C. N.: Direct measurement of volume flux in the Faroe-Shetland Channel and over the Iceland-Faroe Ridge, Geophys. Res. Lett., 39, L07602, doi:10.1029/2012gl051269, 2012.
Schlichtholz, P. and Jankowski, A.: Hydrological regime and water transport in the Faroe-Shetland Channel in summer of 1988 and 1989, Oceanol. Acta, 16, 11-22, 1993.

Sherwin, T. J.: Evidence of a deep internal tide in the FaeroeShetland Channel, in: Tidal Hydrodynamics, 1st Edn., edited by: Parker, B. B., John Wiley, 469-488, 1991.

Sherwin, T. J. and Turrell, W. R.: Mixing and advection of a cold water cascade over the Wyville Thomson Ridge, Deep-Sea Res. Pt. I, 52, 1392-1413, 2005.

Sherwin, T. J., Turrell, W. R., Jeans, D. R. G., and Dye, S.: Eddies and a mesoscale deflection of the slope current in the FaroeShetland Channel, Deep-Sea Res. Pt. I, 46, 415-438, 1999.

Sherwin, T. J., Williams, M. O., Turrell, W. R., Hughes, S. L., and Miller, P. I.: A description and analysis of mesoscale variability in the Faroe-Shetland Channel, J. Geophys. Res., 111, C03003, doi:10.1029/2005JC002867, 2006.

Sherwin, T. J., Griffiths, C. R., Inall, M. E., and Turrell, W. R.: Quantifying the overflow across the Wyville Thomson Ridge into the Rockall Trough, Deep-Sea Res. Pt. I, 55, 396-404, 2008 a.

Sherwin, T. J., Hughes, S. L., Turrell, W. R., Hansen, B., and Østerhus, S.: Wind-driven monthly variations in transport and the flow field in the Faroe Shetland Channel, Polar Res., 27, 7-22, $2008 \mathrm{~b}$.

Souza, A. J., Simpson, J. H., Harikrishnan, M., and Malarkey, J.: Flow Structure and Seasonality in the Hebridean Slope Current, Oceanolog. Acta, 24, 63-76, 2001.

Tait, J. B.: Hydrography of the Faroe-Shetland Channel 1927-1952, Mar. Res. Scotland, 2, 309, 1957.

Turrell, W. R., Hansen, B., Østerhus, S., Hughes, S. L., Ewart, K., and Hamilton, J.: Direct observatons of inflow to the Nordic Seas through the Faroe Shetland Channel 1994-1998, ICES CM1999/L:01, 1999a.

Turrell, W. R., Slesser, G., Adams, R. D., Payne, R., and Gillibrand, P. A.: Decadal variability in the composition of Faroe Shetland Channel Bottom Water, Deep Sea Res. Pt. I, 46, 1-25, 1999b.

van Aken, H. M.: Transports of water masses through the Faroese Channels determined by an inverse method, Deep-Sea Res., 35, 595-617, 1988. 